\title{
Heavy metal contamination and its indexing approach for river water
}

\author{
*R. Reza; G. Singh \\ Department of Environmental Science and Engineering, Indian School of Mines, Dhanbad-826004, Jharkhand, India \\ Received 10 May 2010; ～revised 13 June 2010; accepted 2 August 2010; available online 1 September 2010

\begin{abstract}
The objective of the study is to reveal the seasonal variations in the river water quality with respect to heavy metals contamination. To get the extend of trace metals contamination, water samples were collected from twelve different locations along the course of the river and its tributaries on summer and the winter seasons. The concentrations of trace metals such as cadmium, cromium, copper, cobalt, iron, manganese, nickel, lead, mercury and zinc were determined using atomic absorption spectrophotometer. Most of the samples were found within limit of Indian drinking water standard (IS: 10500). The data generated were used to calculate the heavy metal pollution index of river water. The mean values of HPI were 36.19 in summer and 32.37 for winter seasons and these values are well below the critical index limit of 100 because of the sufficient flow in river system. Mercury and chromium could not be traced in any of the samples in the study area.
\end{abstract}

Keywords: Heavy metal pollution index; Industrial pollution; Seasonal variation

\section{INTRODUCTION}

Rapid urbanization and industrial development during last decade have provoked some serious concerns for the environment. Heavy metals contamination in river is one of the major quality issues in many fast growing cities, because maintenance of water quality and sanitation infrastructure did not increased along with population and urbanization growth especially for the developing countries (Sundaray et al., 2006; Karbassi et al., 2007; Akoto et al., 2008; Ahmad et al., 2010).

Trace metals enter in river from variety of sources; it be can be either natural or anthropogenic (Bem et al., 2003; Wong et al., 2003; Adaikpoh et al., 2005; Akoto et al., 2008). Usually in unaffected environments, the concentration of most of the metals is very low and is mostly derived from the mineralogy and the weathering (Karbassi et al., 2008). Main anthropogenic sources of heavy metal contamination are mining, disposal of untreated and partially treated effluents contain toxic metals, as well as metal chelates from different industries and indiscriminate use of heavy metal-containing fertilizer and pesticides in agricultural fields (Hatje et al., 1998; Amman et al., 2002; Nouri et al., 2006; Nouri et al., 2008). Metals enter into river water from mining areas through various ways such as mine discharge, run-off,

× *Corresponding Author Email: raza_ism@rediffmail.com Tel./Fax: +913262296624 chemical weathering of rocks and soils, wet and dry fallout of atmospheric particulate matter (Macklin et al., 2003; Bird et al., 2003; Kraft et al., 2006; Singh et al., 2008; Venugopal et al., 2009). The mine water, runoff from abandoned watersheds and associated industrial discharges are the major source of heavy metal contamination, total dossolved solid (TDS) and low pH of streams in mining area (USEPA, 1997; Mohanty et al., 2001; Cravotta, 2008; Shahtaheri et al., 2008). Rivers in urban areas have also been associated with water quality problems because of the practice of discharging of untreated domestic and small scale industries into the water bodies which leads to the increase in the level of metals concentration in river water (Rim-Rekeh et al., 2006; Khadse et al., 2008; Juang et al., 2009; Venugopal et al., 2009; Sekabira et al., 2010).

Trace metal contaminations are important due to their potential toxicity for the environment and human beings (Gueu et al., 2007; Lee et al., 2007; Adams et al., 2008; Vinodhini and Narayanan, 2008). Some of the metals like $\mathrm{Cu}, \mathrm{Fe}, \mathrm{Mn}, \mathrm{Ni}$ and $\mathrm{Zn}$ are essential as micronutrients for the life processes in animals and plants while many other metals such as $\mathrm{Cd}, \mathrm{Cr}, \mathrm{Pb}$ and Co have no known physiological activities (Kar et al., 2008; Suthar and Singh, 2008; Aktar et al., 2010). Metals are non-degradable and can accumulate in the human body system, causing damage to nervous 
system and internal organs (Lee et al., 2007; Lohani et al., 2008). However, the rivers play a major role in assimilation or transporting municipal and industrial wastewater and runoff from agricultural and mining land (Singh et al., 2004). The present study aimed to envisage the water quality status of River Brahmani and its tributaries with respect to its heavy metal concentrations in various seasons at Angul district of Orissa. The research work was carried during summer (May, 2008) and winter (January, 2009). Metal concentration in river water in various places of India is illustrated in Table 1.

\section{MATERIALS AND METHODS}

Study area

The study area (Angul-Talcher region) is bounded by latitudes $20^{\circ} 37^{\prime} \mathrm{N}$ to $21^{\circ} 10^{\prime} \mathrm{N}$ and longitudes $84^{\circ}$ $53^{\prime} \mathrm{E}$ to $85^{\circ} 28^{\prime} \mathrm{E}$ and situated at an average height of $139 \mathrm{~m}$ above mean sea level. The river catchment is characterized by Precambrian granites, gneisses and schists of Eastern Ghats with local intrusive and volcanic lithologies; lime stone, sand stone and shales of the Gondwanas (Sene-Johansen, 1995; Panda et al., 2006; Sundaray et al., 2006). The area comes under sub tropic monsoon climate with an average annual rainfall of $1370 \mathrm{~mm}$. The temperature varies from $11.9^{\circ}$ $\mathrm{C}$ to $44.4^{\circ} \mathrm{C}$ (Sundaray et al., 2006). At present, it accommodates several large and medium scale industries such as Nalco Smelter and its Captive Power Plant (CPP-960MW), Talcher Super Thermal Power Station, NTPC (TSTPS-3000MW), Talcher Thermal Power Station (TTP-460MW), Iron and Steel industries and various coal mines. The drainage pattern is controlled by the River Brahmani along with its tributaries. River Brahmini play as a major source of water, as well as sink for effluent for the existing industries. These industrial activities affect various components of ecology and the environment and impart heavy metal contamination in the river water.

\section{Field sampling}

In order to achieve the research objective, samples were collected from twelve different locations of Brahmani River along with its tributaries in AngulTalcher Region to evaluate the heavy metal contamination during various seasons (summer and winter) (Table 2). Criteria for selection of sampling station were based on the locations of industrial units and land use pattern to quantify heavy metal concentration. Five sites were selected along the Brahmani River and seven sites were located along its main four tributaries, named as Tikira River, Bangaru River, Nandira River and Kisinda River (Fig. 1). The Samples were taken from 10 to $15 \mathrm{~cm}$ below the water surface using acid washed plastic container to avoid unpredictable changes in characteristic as per standard procedures (APHA, 1998). Samples were collected in May 2007 for summer season, and in January 2008 samples were collected for winter season. Care was taken to collect subsequent samples from same location in both the seasons.

\section{Laboratory methods}

Water samples were collected from all the respective sampling stations of Brahmani River. The collected samples were filtered (Whatman no. 42) and preserved with $6 \mathrm{~N}$ of $\mathrm{HNO}_{3}$ for further analysis (APHA, 1998). Concentrations of heavy metals in water samples were determined with an atomic absorption spectrophotometer (GCB-Avanta) with a specific lamp for

Table 1: Comparison of dissolved metal concentration with other Indian rivers $(\mu \mathrm{g} / \mathrm{L})$

\begin{tabular}{|c|c|c|c|c|c|c|c|c|c|c|c|}
\hline Metals Rivers & $\mathrm{Fe}$ & $\mathrm{Mn}$ & Co & $\mathrm{Ni}$ & $\mathrm{Cu}$ & $\mathrm{Zn}$ & $\mathrm{Cr}$ & $\mathrm{Pb}$ & $\mathrm{Cd}$ & $\mathrm{Hg}$ & References \\
\hline Subarnarekha river & 66.25 & 11.38 & 1.13 & 15.75 & 15.88 & 23.00 & 1.13 & 19.13 & - & - & Senapati and Sahu (1996) \\
\hline Hindon river & 226.0 & 129.0 & - & 24.0 & 6.6 & 58.0 & 15.0 & 37.0 & - & - & Jain and Sharma (2006) \\
\hline Baitarani river & 100.5 & 1.70 & 0.7 & 3.9 & 3.45 & 272.3 & 9.6 & 3.45 & - & - & Nayak et al., (2001) \\
\hline Mahanadi river & - & 96.9 & 2.4 & 7.2 & 5.9 & 11.0 & 9.8 & 2.68 & - & - & Konhauser et al. (1997) \\
\hline Achankovil river & 11858 & 699 & - & - & 224 & 415 & - & 72 & 6.0 & - & Prasad et al., (2006) \\
\hline $\begin{array}{l}\text { Koel } \\
\text { (Brahmani) river }\end{array}$ & 481.78 & 30.33 & 8.67 & 24.78 & 6.67 & 31.56 & 10.89 & 1.67 & - & - & Sundaray (2009) \\
\hline Ganga river & 800 & 260 & - & 140 & 10 & 60 & - & 120 & 5 & - & Aktar et al., (2010) \\
\hline Damodar river & 480 & & & & 3950 & & 11550 & & 300 & & Chatterjee et al, (2010) \\
\hline Brahmani river & $5-95$ & $1.5-102$ & $4.0-5.6$ & $9-52$ & $1-4.7$ & $0.4-80.1$ & - & $10-27$ & $0.4-4.0$ & - & Present study \\
\hline
\end{tabular}


particular metal. Average values of three replicates were taken for each determination. Appropriate drift blank was taken before the analysis of samples. The working wave length for the heavy metals are $248.3 \mathrm{~nm}$ for Fe, $279.5 \mathrm{~nm}$ for $\mathrm{Mn}, 213.9 \mathrm{~nm}$ for $\mathrm{Zn}, 324.7 \mathrm{~nm}$ for $\mathrm{Cu}, 232$ $\mathrm{nm}$ for Ni, $228.8 \mathrm{~nm}$ for Cd, $357.9 \mathrm{~nm}$ for $\mathrm{Cr}, 217 \mathrm{~nm}$ for $\mathrm{Pb}, 240.7 \mathrm{~nm}$ for Co and 253.7nm for $\mathrm{Hg}$.

\section{Indexing approach}

Heavy metal pollution index (HPI) is a method of rating that shows the composite influence of individual heavy metal on the overall quality of water. The rating is a value between zero and one, reflecting the relative importance individual quality considerations and defined as inversely proposal to the recommended standard (Si) for each parameters. Water quality and its suitability for drinking purpose can be examined by determining its quality index (Mohan et al., 1996; Prasad and Kumari, 2008; Prasad and Mondal, 2008).
The calculation involves the following steps

First, the calculation of weightage of $\mathrm{i}^{\text {th }}$ parameter;

Second, the calculation of the quality rating for each of the heavy metal;

Third, the summation of these sub-indices in the overall index.

The weightage of $\mathrm{i}^{\text {th }}$ parameter is:

$$
\mathrm{W}_{\mathrm{i}}=\mathrm{k} / \mathrm{S}_{\mathrm{i}}
$$

Where, $W_{i}$ is the unit weightage and $S_{i}$ the recommended standard for ith parameter ( $\mathrm{i}=1-6)$, $\mathrm{k}$ is the constant of proportionality.

Individual quality rating is given by the expression

$$
\mathrm{Q}_{\mathrm{i}}=100 \mathrm{~V}_{\mathrm{i}} / \mathrm{S}_{i}
$$

Where, Qi is the sub index of ith parameter, $\mathrm{V}_{\mathrm{i}}$ is the monitored value of the ith parameter in $\mu \mathrm{g} / \mathrm{L}$ and $\mathrm{S}_{\mathrm{i}}$ the standard or permissible limit for the ith parameter.

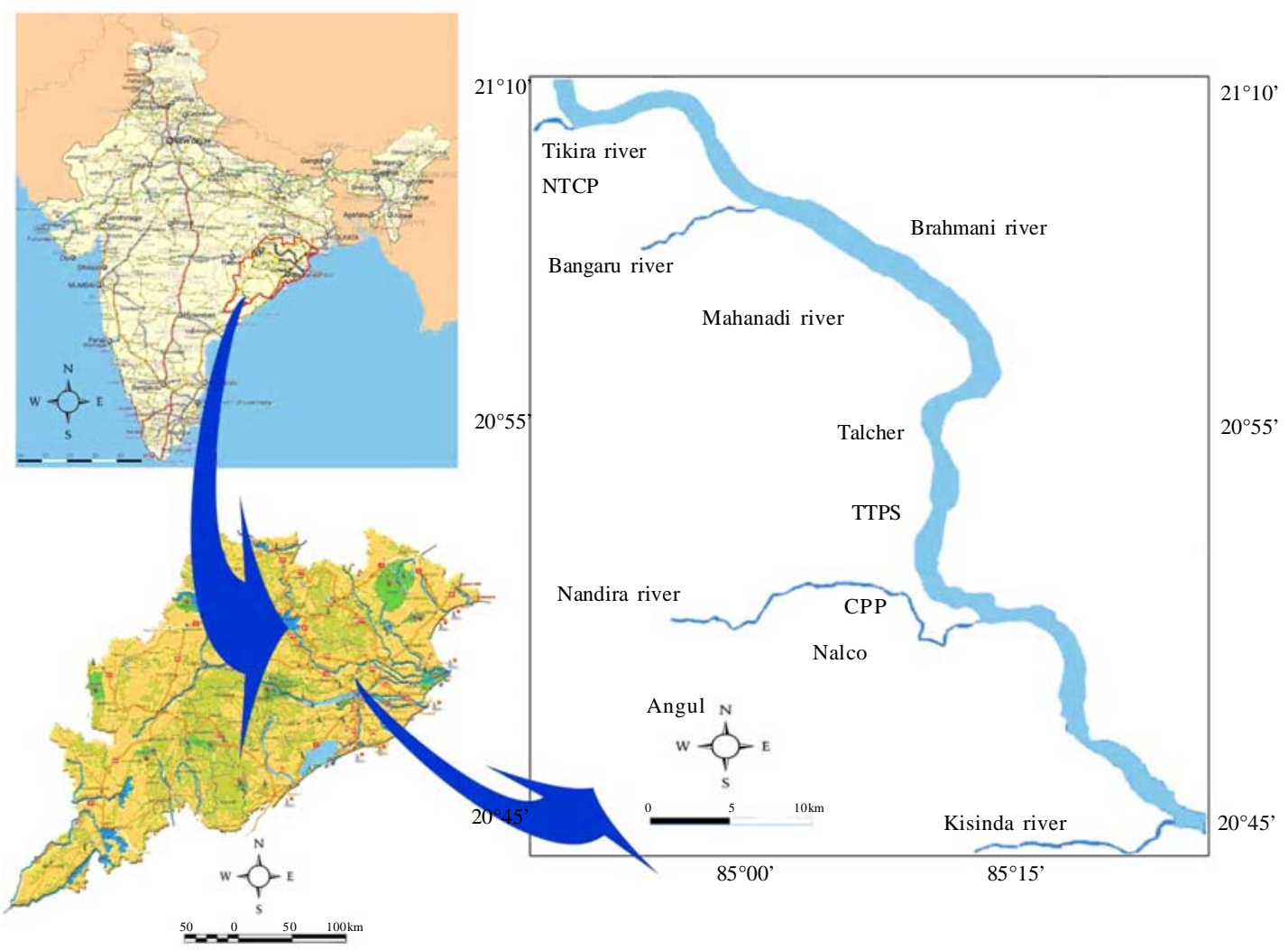

Fig. 1: Geographical representation of the study area 
Heavy metal contamination in river water

Table 2: Details of surface water sampling location along with their longitude and latitude

\begin{tabular}{|c|c|c|c|}
\hline Code & Locations & Longitude & Latitude \\
\hline W1 & Tikira nadi just before meeting Brahmani River & $85^{\circ} 06^{\prime} 07^{\prime \prime}$ & $21^{\circ} 05^{\prime} 40^{\prime \prime}$ \\
\hline W2 & Brahmani river U/S to Tikira river & $85^{\circ} 07^{\prime} 19^{\prime \prime}$ & $21^{\circ} 06^{\prime} 09^{\prime \prime}$ \\
\hline W3 & Brahmani river D/S to Tikira river & $85^{\circ} 06^{\prime} 37^{\prime \prime}$ & $21^{\circ} 04^{\prime} 37^{\prime \prime}$ \\
\hline W4 & Brahmani river near Samal Barrage & $85^{\circ} 08^{\prime} 19^{\prime \prime}$ & $21^{\circ} 04^{\prime} 22^{\prime \prime}$ \\
\hline W5 & Brahamani river U/S to Nandira river & $85^{\circ} 15^{\prime} 31^{\prime \prime}$ & $20^{\circ} 53^{\prime} 30^{\prime \prime}$ \\
\hline W6 & Angul canal, near Kumanda village & $85^{\circ} 05^{\prime} 14^{\prime \prime}$ & $20^{\circ} 50^{\prime} 46^{\prime \prime}$ \\
\hline W7 & Nandirariver, before meeting to Brahamani river & $85^{\circ} 15^{\prime} 35^{\prime}$ & $20^{\circ} 53^{\prime} 16^{\prime \prime}$ \\
\hline W8 & Nandira river near Tentuli village & $85^{\circ} 10^{\prime} 52^{\prime \prime}$ & $20^{\circ} 53^{\prime} 30^{\prime \prime}$ \\
\hline W9 & Brahmani River D/S to Nandira river & $85^{\circ} 53^{\prime} 19^{\prime \prime}$ & $20^{\circ} 53^{\prime} 19^{\prime \prime}$ \\
\hline W10 & Angul canal at Bargadia chowk & $85^{\circ} 02^{\prime} 37^{\prime}$ & $20^{\circ} 51^{\prime} 09^{\prime \prime}$ \\
\hline W11 & Kisinda river, before meeting to Brahamani river & $85^{\circ} 16^{\prime} 55^{\prime \prime}$ & $20^{\circ} 49^{\prime} 03^{\prime \prime}$ \\
\hline W12 & Bangaru river, before meeting to Brahamani river & $85^{\circ} 11^{\prime} 04^{\prime \prime}$ & $21^{\circ} 00^{\prime} 17^{\prime \prime}$ \\
\hline
\end{tabular}

The heavy metal index is then calculated as follows:

HPI $=\sum_{\mathrm{i}=1}^{\mathrm{n}}\left(\mathrm{Q}_{\mathrm{i}} \mathrm{W}_{\mathrm{i}}\right) / \sum_{\mathrm{i}=1}^{\mathrm{n}} \mathrm{W}_{\mathrm{i}}$

Where, Qi is the sub index of ith parameter. $\mathrm{W}_{\mathrm{i}}$ is the unit weightage for ith parameter, $n$ is the number of parameters considered. Generally, the critical pollution index value is 100 .

\section{RESULTS AND DISCUSSION}

The results revealed that in most of the sampling stations, water was slightly alkaline except at very few stations in the upper course of the River where the water was found to be slightly acidic. The range of $\mathrm{pH}$ was 7.6-8.5 during the winter, while in summer it was slightly acidic to alkaline (6.0-8.3). The above values usually indicate the presence of carbonates of calcium and magnesium in water (Begum et al., 2009). High $\mathrm{pH}$ of the River water may result in the reduction of heavy metal toxicity (Aktar et al., 2010). In the case of Total dissolved solids (TDS), there was a considerable amount of dissolved ions in all the sampling locations. Higher concentration of TDS was observed in the River water near the middle part of the River Basin. It was in the range of 166-330 $\mathrm{mg} / \mathrm{L}$ and 164-294 $\mathrm{mg} / \mathrm{L}$ in summer and winter seasons, respectively. Various large and small industries are concentrated in these areas. The effluents from these industries are directed into the River course which increases the concentration of TDS in the water body (Phiri et al., 2005; Rim Rukeh et al., 2006). The concentration ranges, mean and standard deviation of individual metals are illustrated shown in Table 4.
The maximum Fe concentrations were found 64.6 and $95.0 \mu \mathrm{g} / \mathrm{L}$ in summer and winter season respectively. It may be assigned to the soil-water interaction especially within the middle and lower part of the River stretch during winter season. Lead was found in winter season while in summer it was below the detection limit. It may be due to the less soluble of $\mathrm{Pb}$ containing minerals in natural water (Venugopal et al., 2009a; b). The maximum lead concentration in River water were observed as 27.0 $\mu \mathrm{g} / \mathrm{L}$ ) during summer season (Neal et al., 2000). The low values of $\mathrm{Cu}$ indicate there is no significant source of pollution. The maximum $\mathrm{Cu}$ was found $4.7 \mu \mathrm{g} / \mathrm{L}$ and $4.2 \mu \mathrm{g} / \mathrm{L}$ in respective seasons. It may be attributed to domestic sewage and run-off from extensive farmed areas (Wu et al., 2008). The relatively higher concentrations of zinc in some of the sampling stations were $80.1 \mu \mathrm{g} / \mathrm{L}$ and $75.5 \mu \mathrm{g} / \mathrm{L}$ during summer and winter season, respectively. It is attributed to the presence of unused remains of zinc sulphate in fertilizers (Wu et al., 2008). Highest value of Co was found $(5.6 \mu \mathrm{g} / \mathrm{L})$ in summer season, it may be due to effluent from metal alloys industries (Brian and Bishop, 2009). The major source of $\mathrm{Cd}$ is the coal combustion, metal industry and waste incineration (Brian and Bishop, 2009). The maximum concentration $\mathrm{Cd}$ in the area was $4.0 \mu \mathrm{g} / \mathrm{L}$ in summer season. It may be due to coal- combustion which is very frequent in industries (Thermal Power Station) and domestic purpose. The maximum value of $\mathrm{Ni}$ was $52 \mu \mathrm{g} / \mathrm{L}$ in winter while $\mathrm{Mn}$ was $102 \mu \mathrm{g} / \mathrm{L}$ during summer season. The concentration of $\mathrm{Hg}$ and $\mathrm{Cr}$ could not be detected in any of the samples. Most of the dissolved heavy metals showed slightly high concentrations during the summer period than that 
Int. J. Environ. Sci. Tech., 7 (4), 785-792, Autumn 2010

Table 3: HPI calculation for the surface water based on the Indian drinking water standard (IS: 10500, 1993)

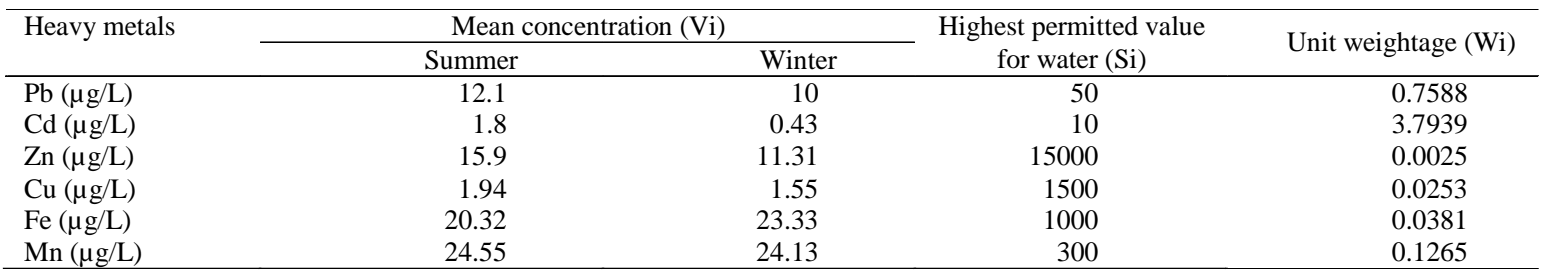

Table 4: Statistical Variation (Range, Mean and Standard deviation) among various heavy metals

\begin{tabular}{|c|c|c|c|c|c|}
\hline \multirow[t]{2}{*}{ Parameters } & \multicolumn{2}{|c|}{ Summer } & \multicolumn{2}{|c|}{ Winter } & \multirow{2}{*}{$\begin{array}{c}\text { Detection Limits } \\
\text { (GBC-Avanta) }\end{array}$} \\
\hline & Range & Mean \pm SD & Range & Mean \pm SD & \\
\hline $\mathrm{pH}$ & $6.0-8.3$ & $7.5 \pm 0.70$ & $7.6-8.5$ & $8.0 \pm 0.200$ & - \\
\hline TDS (mg/L) & $166-330$ & $254 \pm 53.1$ & $164-294$ & $219 \pm 4000$ & - \\
\hline $\mathrm{Pb}(\mu \mathrm{g} / \mathrm{L})$ & $<10.0-27.0$ & $12.08 \pm 5.23$ & $<10.0$ & - & 10.0 \\
\hline $\mathrm{Cd}(\mu \mathrm{g} / \mathrm{L})$ & $<0.40-4.00$ & $1.80 \pm 1.93$ & $<0.40-0.70$ & $0.43 \pm 0.10$ & 0.04 \\
\hline $\mathrm{Hg}(\mu \mathrm{g} / \mathrm{L})$ & $<0.05$ & - & $<0.05$ & - & 0.05 \\
\hline $\mathrm{Zn}(\mu \mathrm{g} / \mathrm{L})$ & $<0.40-80.1$ & $15.90 \pm 28.51$ & $<0.40-75.50$ & $11.31 \pm 21.4$ & 0.4 \\
\hline $\mathrm{Cu}(\mu \mathrm{g} / \mathrm{L})$ & $<1.0-4.70$ & $1.94 \pm 1.250$ & $<1.0-4.200$ & $1.55 \pm 0.90$ & 1.0 \\
\hline $\mathrm{Ni}(\mu \mathrm{g} / \mathrm{L})$ & $<9.0-44.3$ & $15.73 \pm 12.16$ & $<9.0-52.00$ & $16.35 \pm 13.2$ & 9.0 \\
\hline $\mathrm{Fe}(\mu \mathrm{g} / \mathrm{L})$ & $<5.0-64.6$ & $20.32 \pm 20.89$ & $<5.0-95.00$ & $23.33 \pm 27.8$ & 5.0 \\
\hline Co $(\mu \mathrm{g} / \mathrm{L})$ & $<4.0-5.60$ & $4.13 \pm 0.640$ & $<4.0-5.30$ & $4.14 \pm 0.40$ & 4.0 \\
\hline $\mathrm{Mn}(\mu \mathrm{g} / \mathrm{L})$ & $<1.5-102$ & $24.55 \pm 33.74$ & $1.50-98.0$ & $24.13 \pm 32.9$ & 1.5 \\
\hline $\mathrm{Cr}(\mu \mathrm{g} / \mathrm{L})$ & $<3.00$ & - & $<3.00$ & - & 3.0 \\
\hline
\end{tabular}

of the winter season. These kinds of pattern indicate the accumulation of the metal concentration during low flow condition of River. It may be attributed to high evaporation rate of surface water followed by elevated temperature (Abdel-Satar, 2001). Few metals such as $\mathrm{Fe}$ and Ni were high during winter, it may be due to the effect of rain (Phiri et al., 2005). The previous studies has been ensure that the atmospheric precipitation is very much responsible for metal contamination in surface water (Wong et al., 2003; Wu et al., 2008; Pandey et al., 2009).

Statistical tests showed that the metal concentrations were significantly different between sampling stations. It was also observed that for all (ten) metals studied; there was a trend of increasing concentrations from the upstream stations to the downstream stations.

In order to calculate the HPI of the water, the mean concentration value of the selected metals ( $\mathrm{Pb}, \mathrm{Cd}$, $\mathrm{Zn}, \mathrm{Cu}, \mathrm{Fe}, \mathrm{Mn}$ ) have been taken into account (Prasad and Mondal, 2008). Table 3 details the calculations of HPI with unit weightage (Wi) and standard permissible value ( $\mathrm{Si}$ ) as obtained in the presented study. The mean of heavy metal pollution index values are 36.19 and 32.37 in summer and winter season, respectively, while the maximum value of HPI was (66.15) found at sampling location (w11) in summer season. It may be attributed to domestic sewage. The critical pollution index value, above which the overall pollution level should be considered unacceptable, is 100 (Prasad and Kumari, 2008; Prasad and Mondal, 2008). This indicates the water is not critically polluted with respect to heavy metals.

\section{CONCLUSION}

The present study reveals that most of the water samples of River system at Angul were found less polluted in heavy metal contamination profile and shows a trend in seasonal variation. Very few samples evidenced the slightly significant metal concentration in water samples in the middle of the River catchment during summer season. It is attributed to the concentration of various mines and associated industries along with the River course.

The HPI is very useful tool in evaluating over all pollution of water bodies with respect to heavy metals (Prasad and Kumari, 2008). The HPI values of the present study indicate that the water samples from the River are not critically contaminated with 
respect to heavy metals. It is due to presence of enough flow rate of River water, the metal concentration from mine water and other industrial effluents has been diluted rapidly with respect to a very small distance. More over metal pollution by mining and associated industrial activities is somewhat mitigated because of strict implementation of clean technology and environmental measures by industries.

\section{ACKNOWLEDGEMENTS}

The authors are thankful to State Pollution Control Board Orissa, for sponsoring this study. Authors are also grateful to professor T. Kumar, Director, ISM to providing research facilities. One of the authors (Rizwan Reza) is grateful to Indian School of Mines/ MHRD/Government of India, for granting a great support.

\section{REFERENCES}

Abdel Satar, A. M., (2001). Environmental studies on the impact of the drains effluent upon the southern sector of Lake Manzalah. Egypt. J. Aquat. Biol. Fish, 5, 17-30 (14 pages).

Adaikpoh, E. O.; Nwajei, G. E.; Ogala, J. E., (2005). Heavy metals concentrations in coal and sediments from river Ekulu in Enugu, Coal City of Nigeria. J. Appl. Sci. Environ. Manag., 9 (3), 5-8 (4 pages).

Adams, R. H.; Guzmán Osorio, F. J.; Zavala Cruz, J., (2008). Water repellency in oil contaminated sandy and clayey soils. Int. J. Environ. Sci. Tech., 5 (4), 445-454 (10 pages).

Ahmad, M. K.; Islam, S.; Rahman, S.; Haque, M. R.; Islam, M. M., (2010). Heavy metals in water, sediment and some fishes of Buriganga River, Bangladesh. Int. J. Environ. Res., 4 (2), 321-332 (12 pages).

Akoto, O.; Bruce, T. N.; Darko, G., (2008). Heavy metals pollution profiles in streams serving the Owabi reservoir. African J. Environ. Sci. Tech., 2 (11), 354-359 (6 pages).

Aktar, M. W.; Paramasivam, M.; Ganguly, M.; Purkait, S.; Sengupta, D., (2010). Assessment and occurrence of various heavy metals in surface water of Ganga river around Kolkata: a study for toxicity and ecological impact. Environ. Monitor. Assess., 160 (1-4), 207-213 (7 pages).

Ammann, A. A.; Michalke, B., Schramel, P., (2002). Speciation of heavy metals in environmental water by ion chromatography coupled to ICP-MS. Anal. Bioanal. Chem., 372 (3), 448-452 (5 pages).

APHA, (1998) Standard methods for examination of water and waste water $\left(20^{\text {th. Ed. }}\right.$. Washington DC: American Public Health Association.

Begum, A.; Ramaiah, M.; Khan, H. I.; Veena, K., (2009). Heavy metal pollution and chemical profile of Cauvery River Water. E-J. Chem., 6 (1), 47-52 (6 pages).

Bem, H.; Gallorini, M.; Rizzio, E.; Krzemin, S. M., (2003). Comparative studies on the concentrations of some elements in the urban airparticulate matter in Lodz City of Poland and in Milan, Italy. Environ. Int., 29 (4),423428 (6 pages).

Bird, G.; Brewer, P.; Macklin, M.; Balteanu, D.; Driga, B.; Serban, M.; Zaharia, S., (2003). The solid state partitioning of contaminant metals and As in river channel sediments of the mining affected Tisa drainage basin, northwestern Romania and eastern Hungary. Appl. Geochem., 18 (10), 1583-1595 (13 pages).

Brian, S. C.; Bishop, M., (2009). Seasonal and spatial variation of metal loads from natural flows in the upper Tenmile Creek watershed, Montana. Mine Water Environ., 28 (3), 166-181 (16 pages).

Chatterjee, S. K.; Bhattacharjee, I.; Chandra, G.; (2010). Water quality assessment near an industrial site of Damodar River, India. Environ. Monitor. Assess., 161 (1-4), 177-189 (13 pages).

CravottaIII, A. C., (2008). Dissolved metals and associated constituents in abandoned coal-mine discharges, Pennsylvania, USA. Part 1: Constituent quantities and correlations. Appl. Geochem., 23 (2), 166-202 (37 pages).

Gueu, S.; Yao, B.; Adouby, K.; Ado, G. (2007). Kinetics and thermodynamics study of lead adsorption on to activated carbons from coconut and seed hull of the palm tree. Int. J. Environ. Sci. Tech. 4 (1), 11-17 (6 pages).

Hatje, V.; Bidone, E. D.; Maddock, J. L., (1998). Estimation of the natural and anthropogenic components of heavy metal fluxes in fresh water Sinos river, Rio Grande do Sul state, South Brazil. Environ. Tech., 19 (5), 483-487 (5 pages).

IS 10500, (1993). Indian drinking water standards. Indian standard specifications for drinking water.

Jain, C. K.; Sharma, M. K., (2006). Heavy metal transport in the Hindon river basin, India. Environ. Monitor. Assess., 112 (1-3), 255-270 (16 pages).

Juang, D. F.; Lee, C. H.; Hsueh, S. C., (2009). Chlorinated volatile organic compounds found near the water surface of heavily polluted rivers. Int. J. Environ. Sci. Tech., 6 (4), 545-556 (12 pages).

Kar, D.; Sur, P.; Mandal, S. K.; Saha, T.; Kole, R. K., (2008). Assessment of heavy metal pollution in surface water., Int. J. Environ. Sci. Tech., 5 (1), 119-124 (6 pages).

Karbassi, A. R.; Monavari, S. M.; Nabi Bidhendi, G. R.; Nouri, J.; Nematpour, K., (2008). Metal pollution assessment of sediment and water in the Shur River. Environ. Monitor. Assess., 147 (1-3), 107-116 (12 pages).

Karbassi, A. R.; Nouri, J.; Ayaz, G. O., (2007). Flocculation of trace metals during mixing of Talar river water with Caspian Seawater. Int. J. Environ. Res., 1 (1), 66-73 (8 pages).

Khadse, G. K.; Patni, P. M.; Kelkar, P. S.; Devotta, S., (2008).Qualitative evaluation of Kanhan river and its tributaries flowing over central Indian plateau. Environ. Monitor. Assess., 147 (1-3), 83-92 (10 pages).

Konhauser, K. O.; Powell, M. A.; Fyfe, W. S.; Longstaffe, F. J.; Tripathy, S., (1997). Trace element chemistry of major rivers in Orissa State, India. Environ. Geo., 29 (12), 132-141 (10 pages).

Kraft, C.; Tumpling, W.; Zachmann, D.W.; (2006). The effects of mining in Northern Romania on the heavy metal distribution in sediments of the rivers Szamos and 
Tisza (Hungary). Acta Hidrochim. Hhydrobiol., 34, 257264 (8 pages).

Lee, C. L.; Li, X. D.; Zhang, G.; Li, J.; Ding, A. J.; Wang, T., (2007). Heavy metals and $\mathrm{Pb}$ isotopic composition of aerosols in urban and suburban areas of Hong Kong and Guangzhou, South China Evidence of the long-range transport of air contaminants. Environ. Pollut., 41 (2), 432-447 (16 pages).

Lohani, M. B.; Singh, S.; Rupainwar, D. C.; Dhar, D. N., (2008). Seasonal variations of heavy metal contamination in river Gomti of Lucknow city region. Environ. Monitor. Assess., 147 (1-3), 253-263 (11 pages). Macklin, M. G.; Brewer, P. A.; Balteanu, D.; Coulthard, T. J.; Driga, B.; Howard, A. J.; Zaharia, S., (2003). The long term fate and environmental significance of contaminant metals released by the January and March 2000 mining tailings dam failure in Maramures County, upper Tisa basin, Romania. Appl. Geochem., 18 (2), 241-257 (17 pages).

Mohan, S. V.; Nithila, P.; Reddy, S. J., (1996). Estimation of heavy metal in drinking water and development of heavy metal pollution index. J. Environ. Sci. Health A., 31 (2), 283-289 (7 pages).

Mohanty, J. K.; Misra, S. K.; Nayak, B. B., (2001). Sequential leaching of trace elements in coal: A case study from Talcher coalfield, Orissa. J. Geo. Soc. India, 58, 441-447 (8 pages).

Nayak, B. B.; Panda, U. C.; Panigrahy, P. K.; Acharya, B. C.; (2001). Dynamics of heavy metals in Dhamara Estuary of Orissa state in India. Chem. Environ. Res., 10 (3-4), 203-218 (16 pages).

Neal, C.; Jarvie, H. P.; Whitton, B. A.; Gemmell, J.; (2000). The water quality of the River Wear, north-east England. Sci. Total Environ., 251-252,153-172 (20 pages).

Nouri, J.; Mahvi, A. H.; Babaei, A.; Ahmadpour, E., (2006). Regional pattern distribution of groundwater fluoride in the Shush aquifer of Khuzestan County Iran Fluoride. Fluoride., 39 (4), 321-325 (5 pages).

Nouri, J.; Mahvi, A. H.; Jahed, G. R.; Babaei, A. A., (2008). Regional distribution pattern of groundwater heavy metals resulting from agricultural activities. Environ. Geo., 55 (6), 1337-1343 (7 pages).

Panda, U. C.; Sundaray, S. K. ; Rath, P.; Nayak, B. B.; Bhatta, D., (2006). Application of factor and cluster analysis for characterization of river and esturine water system-A case study: Mahanadi River (India). J. Hydro., 331 (3-4), 434445 (12 pages).

Pandey, J.; Shubhashish, K.; Pandey, R.; (2009). Metal contamination of Ganga River (India) as influenced by atmospheric deposition. Bull. Environ. Contam. Toxicol., 83 (2), 204-209 (6 pages).

Phiri, O.; Mumba, P.; Moyo, B. H. Z.; Kadewa, W., (2005). Assessment of the impact of industrial effluents on water quality of receiving Rivers in urban areas of Malawi. Int. J. Environ. Sci. Tech., 2 (3), 237-244 (8 pages).

Prasad, B.; Kumari, S., (2008). Heavy metal pollution index of ground water of an abandoned open cast mine filled with fly ash: A case study. Mine Water Environ., 27 (4), 265-267 (3 pages).

Prasad, B.; Mondal, K. K., (2008). The impact of filling an abandoned opencast mine with fly ash on ground water quality: A case study. Mine Water Environ., 27 (1), 40-45 (6 pages).

Prasad, M. B. K.; Ramanathan, A. L.; Shrivastav, S. K.; Anshumali.; Rajinder, S., (2006). Metal fractionation studies in surfacial and core sediments in the Achankovil river basin in India. Environ. Monitor. Assess., 121 (1-3), 77-102 (26 pages).

Rim-Rukeh, A.; Ikhifa, O. G.; Okokoyo, A. P., (2006). Effects of agricultural activities on the water quality of Orogodo River, Agbor Nigeria. J. Appl. Sci. Res., 2 (5), 256-259 (4 pages).

Sekabira, K.; Oryem Origa, H.; Basamba, T. A.; Mutumba, G.; Kakudidi, E., (2010). Assessment of heavy metal pollution in the urban stream sediments and its tributaries. Int. J. Environ. Sci. Tech., 7 (3), 435-446 (12 pages).

Senapati, N. K.; Sahu, K. C., (1996). Heavy metal distribution in Subarnarekha river east coast of India. Indian J. Mar. Sci., 25 (2), 109-114 (6 pages).

Sene-Johansen, S., (1995). Strengthening of the state pollution control board, Orissa State. International Consultant Report, Norway.

Shahtaheri, S. J.; Abdollahi, M.; Golbabaei, F.; RahimiFroushani, A.; Ghamari, F., (2008). Monitoring of mandelic acid as a biomarker of environmental and occupational exposures to styrene. Int. J. Environ. Res., 2 (2), 169176 (8 pages).

Singh, K. P.; Mallik, A.; Mohan, D.; Sinha, S., (2004). Multivariate statistical techniques for the evalution of spatial and temporal variations in water quality of Gomti river (India): A case study. Water Res., 38 (18), 39803992 (13 pages).

Singh, A. K.; Mondal, G. C.; Kumar, S.; Singh, T. B.; Tewary, B. K.; Sinha, A., (2008). Major ion chemistry, weathering processes and water quality assessment in upper catchment of Damodar River basin, India. Environ. Geo., 54 (4), 745-758 (13 pages).

Sundaray, S. K., (2009). Application of multivariate statistical techniques in hydro-geochemical studies-a case study: Brahmani-Koel River (India). Environ. Monitor. Assess., 164 (1-4), 297-310 (14 pages).

Sundaray, S. K.; Panda, U. C.; Nayak, B. B.; Bhatta, D., (2006). Multivariate statistical techniques for the evaluation of spatial and temporal variation in water quality of Mahanadi river-estuarine system (India). A case study. Environ. Geochem. Health, 28 (4), 317-330 (14 pages).

Suthar, S.; Singh, S., (2008). Vermicomposting of domestic waste by using two epigeic earthworms (Perionyx excavatus and Perionyx sansibaricus). Int. J. Environ. Sci. Tech., 5 (1), 99-106 (8 pages).

USEPA, (1997). National Hardrock Mining Framework, EPA., 833-B-97-003

Venugopal, T.; Giridharan, L.; Jayaprakash, M.; Velmurugan, P.M., (2009a). A comprehensive geochemical evaluation 
of the water quality of River Adyar, India. Bull. Environ. Contam. Toxicol., 82 (2), 211-217 (7 pages).

Venugopal, T.; Giridharan, L.; Jayaprakash, M., (2009b). Characterization and risk assessment studies of bed sediments of River Adyar-An application of speciation study. Int. J. Environ. Res., 3 (4), 581-598 (18 pages).

Vinodhini, R.; Narayanan, M., (2008). Bioaccumulation of heavy metals in organs of fresh water fish Cyprinus carpio (Common carp). Int. J. Environ. Sci. Tech., 5 (2), 179-

\section{2 (4 pages).}

Wong, C. S. C.; Li, X. D.; Zhang, G.; Qi, S. H.; Peng, X. Z., (2003). Atmospheric deposition of heavy metals in the Pearl River Delta, China. Atmos. Environ., 37 (6), $767-$ 776 (10 pages).

Wu, Y. F.; Liu, C. Q.; Tu, C. L., (2008). Atmospheric deposition of metals in TSP of guiyang, PR China. Bull. Environ. Contam. Toxicol., 80 (5), 465-468 (4 pages).

\section{AUTHOR (S) BIOSKETCHES}

Reza, R., Ph.D. Candidate, Department of Environmental Science \& Engineering, Indian School of Mines, Dhanbad-826004, Jharkhand, India. Email: raza_ism@rediffmail.com

Singh, G., Ph.D., Professor and Head, Department of Environmental Science and Engineering, Indian School of Mines, Dhanbad-826004, Jharkhand, India. Email: s_gurdeep2001@yahoo.om

How to cite this article: (Harvard style)

Reza, R.; Singh, G., (2010). Assessment of heavy metal contamination and its indexing approach for river water. Int. J. Environ. Sci. Tech., 7 (4), 785-792. 